\title{
The Study of International Trade Specialized Curriculum System Based On Cross-Border E-Commerce
}

\author{
Xiu-Dan Huang \\ Shenyang, China \\ E-mail: 459286694@qq.com
}

\begin{abstract}
At present, with the rapid development of Internet technology and E-commerce, "Internet trade" has spawned the booming of cross-border E-commerce. The development of foreign trade industry has appeared a new tendency; the management technology and methods are experiencing a change and national policy is stepping up efforts to support it. In such a new situation, the curriculum system of higher vocational professional international trade practice should conform to the development of the times to adjust, make the cross-border E-commerce a new direction in the major of higher vocational foreign trade adapting to market changes and maintaining sustainable development of foreign trade.
\end{abstract}

Keywords-cross-border E-commerce; Internet; the curriculum system

\section{INTRODUCTION}

In recent years, the rapid development of cross-border E-commerce has become new ways and new means of international trade, which has important and far-reaching significance in expanding overseas marketing channels, enhancing the brand competitiveness in our country, realizing transformation and upgrading of China's foreign trade. The leaders of the State Council who attache great importance to cross-border e-commerce, accelerate the development of China's cross-border e-commerce have instructed for many times, asking for each department to raise awareness of accelerating the development of cross-border e-commerce. The development of vocational education should adapt to the change of national policy and the actual economic development, adjust the direction of professional development timely. From the past situations of visiting companies, the biggest obstacle of small and medium-sized enterprises engaged in the foreign trade e-commerce is talent, language, culture, and the lack of e-commerce skills resulting in lacking of the ability to sell goods available. Enterprises are in great demand for talents of cross-border electronic commerce, so to speak, in short supply. So direction of professional development adjusted to cross-border e-commerce will conform to the requirements of the policy, the development direction of the times action.

\section{THE BASIC PRESENT SITUATION OF INTERNATIONAL TRADE SPECIALIZED CURRICULUM SYSTEM IN THE HIGHER VOCATIONAL COLLEGES}

With the acceleration of world economic integration, China's foreign trade has developed rapidly, Which will no doubt greatly increases the market demand for international trade professionals. In recent years, however, there are some contradictions of the international trade of professional graduate employment recession phenomenon in higher vocational colleges. According to the author's research practice, the main reason is that some higher vocational colleges in the professional curriculum system failed to arrange course on the organic connection between curriculum according to the social and economic development situation, leading to the graduates who are difficult to put what they have learned into practice and difficult to meet the needs of the company of foreign trade industry. As is known to all, with the rising of cross-border electricity in the domestic country, many small and medium-sized foreign trade enterprises faced with the pressure of transformation and upgrading, they are in urgent need of the talents of cross-border electricity business, and the rapid development of the domestic various cross-border e-commerce platform also needs a large number of relevant personnel to join them. The international trade specialized in cross-border electricity business culture in the most of the higher vocational colleges at present, still exist the following problems: first, the lack of cross-border electricity teaching staff. The teacher has no experience in foreign trade business, no more cross-border electricity business management experience, for the marketing concept, customer maintenance, product marketing and so on basic is an armchair strategist; second, lacking the support of related courses. Generally the courses of international trade at the present stage is the practice of international trade, import and export documents, foreign trade correspondence, customs declaration, etc. Cross-border need electricity businessmen to the cultivation of comprehensive international trade professional and e-commerce professional core courses, and international trade professional basically do not have open an international market network marketing at present stage, cross-border e-commerce and other lessons. 
From the current situations of the curriculum system of international trade specialty in higher vocational colleges, there are mainly two systems: one is the emphasis of traditional theoretical knowledge neglecting practical skills of center type subject curriculum system. The main characteristic of this system is based on the classification of disciplines, by means of knowledge. Cultivate the students according to this system, a solid theoretical foundation, but poor practice ability, who are difficult to adapt to the actual needs of foreign trade position. Another kind is emerging with the employment as the guidance, with the concept of work-flow jobs applied course system. This is also a current relatively popular, widely used curriculum system.

\section{ANALYSIS FOR ENTERPRISE DEMAND OF CROSS-BORDER E-COMMERCE TALENTS SECTION HEADINGS}

According to the data released by the National Bureau of Statistics of the People's Republic of China at the beginning of 2015, among more than 40 million small and medium-sized enterprises in China, nearly 5 million enterprises concentrate on foreign-trade export business, while these enterprises create more than $60 \%$ of total exports of China's foreign trade, which would be called really powerful and important.

But among these nearly 5 million small and medium-sized foreign trade enterprises, only about 200000 enterprises developed Cross-border e-commerce business through all kinds of platform. There are quite a number of enterprises haven't developed Cross-border e-commerce business, or in the transition period of groping.

Fortunately, the condition is not so strictly for small and medium-sized enterprises to develop Cross-border e-commerce business, and these enterprises have high enthusiasm to develop Cross-border e-commerce business as well, so, the number of enterprises which registered on cross-border e-commerce business platform has an annual increase. It is estimated by the Ministry of Commerce of the People's Republic of China, small and medium-sized enterprises and self-employed businessman have already accounts for more than $90 \%$ of the new operators registered on cross-border e-commerce business platform annually.

It can be clearly seen, these small and medium-sized enterprises which have flexible management, urgently waiting to adapt to the new foreign trade development situation, want to development business, occupy the market in cross-border e-commerce business, may become indispensable and conclusive power in the future of China's cross-border e-commerce field. This group has large and urgent needs for talents who were familiar with operating cross-border e-commerce business.

When enterprises developed cross-border e-commerce business, they usually draw support from cross-border e-commerce business platform in the initial stage. These enormous demands advance the further development of e-commerce business platform. According to the incomplete statistics of the Ministry of Commerce, there are more than 5000 cross-border e-commerce business platform enterprises.
They have large and urgent needs for talents who were familiar with technical skills to operate cross-border e-commerce.

Except the private enterprise are contesting the e-commerce market, many cross-border e-commerce business Industrial parks dominated by government are sparing no effort to participate in this field. They response to the call of the state council positively, strongly advanced cross-border e-commerce business by local bonded zone. These constantly mature e-commerce business industrial parks absorbed a large number of domestic and foreign enterprises which engaged in the import and export business and international logistics business. These enterprises have large and urgent needs for talents who can conduct online and offline services, including Online operations, logistics distribution, international payments, customs clearance commodity inspection and other works.

\section{INTERNATIONAL TRADE COURSE SYSTEM REFORM MEASURES}

Currently, developing the profession of cross-border E-commerce in foreign trade profession for higher vocational education is a necessary measure in the trend of 'upgrading' traditional industry to adapt to the development business in today's world.

The process of upgrading the system is basing on existing conditions of foreign trade profession, depending on the training objective which is the talent needs from cross-border electricity suppliers, integrating related professional resources, referring to relevant professional training mode, curriculum teaching mode and the process of curriculum system, then proposes a suitable training model and curriculum for cross-border E-business personnel.

\section{A. Optimizations on professional curriculums and rational adjustments on the teaching content}

Development of cross-border E-commerce in China has brought new opportunities for international trade graduates.

In terms of the demands from cross-border electricity suppliers industry and required working ability for career practice, the international trade profession needs to adjust the curriculum.

On one hand, the traditional international trade theory and practice of international trade, foreign correspondence, foreign trade documents and the whole process of international trade training and other core curriculums should be retained. On the other hand, it is necessary to establish cross-border electricity supplier-related theoretical courses and practical courses, such as E-commerce theory, network marketing, web design, and other training courses on cross-border E-commerce operations.

Students who master the necessary theoretical and practical knowledge can negotiate with foreign corporations in the use of training platforms and channels, engaging in practical cross-border E-business, while outstanding individuals can achieve self-employment or start up a entrepreneurship when they are still on campus. Teaching 
content should be adjusted reasonably according to the abilities that cross-border electricity trade business suppliers hope from a talent. Each school should clarify its ideas on 'what to learn' and 'how to learn', and find ways on how to reform and make innovation on facilitate professional coordination connecting chain links of international trade, commerce, logistics management and other professional specialties.

1) Capability analysis on cross-border E-business positions:

In study, we learned that the required e-business people can be divided into four types: type of business management, business operation, technology-based management and technical operation. For technical operational jobs, companies are more willing to employ graduates with a profession of computer and internet in most cases. Training students to the type of business operation should be the main target in E-business major of higher vocational education, which very nature is "Electronic is means, business is essential". Therefore, under the context of cross-border E-commerce, students with a degree of international trade profession should turn to "technic supported and business-oriented" positions after their graduation.

2) China World Trade Center Professional Curriculum Optimization:

The optimization of the curriculum system of the international trade practice must be based on the requirements of the enterprise position ability. At present, the international trade practice professional job skill requirements is divided into several aspects: business operating skills of foreign trade, foreign trade, English skills, cross-border business operations skills, cross-border Internet marketing skills and international logistics operation skills, which after three aspects reflects the cross-border trade business under the situation of international trade practice teaching reform in the major direction and trend. On this basis, the international trade practice professional core curriculum optimization before and after the comparison as shown in table 1.

TABLE I. THE INTERNATIONAL TRADE PRACTICE PROFESSIONAL CORE CURRICULUM OPTIMIZATION BEFORE AND AFTER THE COMPARISON

\begin{tabular}{|l|l|}
\hline \multicolumn{1}{|c|}{ Before the reform of core courses } & \multicolumn{1}{c|}{ After the reform plans to set up core courses: } \\
\hline International trade practice & International trade practice \\
\hline Foreign trade documents & Foreign trade documents \\
\hline Foreign trade documentary practice & Cross-border e-commerce \\
\hline Foreign trade correspondence & Business English correspondence \\
\hline International marketing & The network marketing \\
\hline International business negotiation & Communication management practices \\
\hline International commercial law & Cross-border legal laws and regulations \\
\hline Foreign trade English dialogue & Cross-border network platform operation \\
\hline
\end{tabular}

\section{B. Scientifically Design the Teaching Project and Improve the Evaluation Mechanism}

The characteristics of the cross-border e-commerce practical and feasible determines its teaching cannot use as evaluation standard in the form of traditional knowledge test. The evaluation and feedback of he cross-border e-commerce teaching can be case study, role-play, project assessment, business performance and so on. The Assessment of partitioning can be used as evaluation. The traditional way of teaching evaluation is a question paper in the final exam, combined with the usual result and experiment result as the final. But by partitioned examination way, the whole teaching process is divided into modules, and assess separately. Evaluate in a variety of forms at the end of each module teaching; synthesize the each module assessment grades as the final. According to the characteristics of the cross-border e-commerce, Evaluation also can break through to individual appraisal for the unit limits, three to five people team as the evaluation unit; reflect the students' team consciousness, cooperation consciousness and other entrepreneurial abilities.

\section{Enhance the University-Enterprise Cooperation Builds the Docking System of Industry and Enterprise}

In the process of talent training, we should seek the cooperation with enterprises actively, formulate the plan of talent training, develop the curriculum standard, build the curriculum resources, organize double-teachers team, build the practice base and promote employment together. We should visit the typical enterprises of employment deeply; collect the enterprises' specific opinions about the talent cultivation besides the early stage of the researches in building the curriculum system. We need internalize the enterprises' opinions to the specific courses when build the curriculum system. Invite the experts to have 2-3 courses, develop the Counterpart employment ability. For example, cooperate with Alibaba speed sell tong, eaby, Dunhuang network and so on. I $\mathrm{n}$ the process of investigation, the Companies surveyed like to cooperate with the Colleges and universities. The ways of cooperation can be various, includes providing students with supply of goods, sending interns field work, receiving the teachers to take a temporary post to develop abilities, Recommending graduates, Sending student teachers to give lectures and so on. In the process of 
constructing curriculum system, we should insist on the docking system of the course system and professional jobs and the thinking of professional courses docking with the job requirements, according to Ap follow-up relationship of the working process of reasonable arrangement, implement" project teaching", "Module teaching", "Task driven" teaching methods, make the students to the position of zero, as soon as possible.

\section{TO PROMOTE THE IMPLEMENTATION OF CROSS-BORDER E-COMMERCE UNDER THE BACKGROUND OF INTERNATIONAL TRADE PRACTICE COURSE OF TALENT CULTIVATION SYSTEM, MAIN APPROACHES INCLUDE}

It is necessary for the major of foreign trade in the current higher vocational colleges to strengthen cross-border e-commerce specialty industry in order to adapt to the development trend of industry to "upgrade. The process of upgrading should be based on the existing foreign trade major educational condition, according to requirements of training target to cultivate the traders of cross-border electricity and integrate related resources in a reference to related professional personnel training mode, the process of practice teaching mode, curriculum system, to put forward a set of suitable training mode and curriculum system.

First, deepen the cooperation pattern between production and education, to carry out the modern apprenticeship.

In September 2014, the ministry of education issued the work opinion "pilot implementation of modern apprenticeship "(faculty into [2014] 9) explicitly pointed out developing modern apprenticeship, realizing comprehensive docking to the major setting and requirements of industry, curriculum content and professional standards, teaching process and the production process, and so on in order to improve the pertinence and the quality of talent training in the practice of international trade professional. In the process of the development of curriculum reform, implement modern apprenticeship carefully, advance integration of the practice of international trade professional admissions and recruitment, and improve students' learning enthusiasm. At the same time, promote the mutually Share of external electricity between foreign trade enterprise and the school full-time teachers, jointly set up operation and teaching quality monitoring system, to ensure the practice of international trade specialty courses.

Second, guide professional qualification and skills contest effectively.

For many years, the provincial education department, foreign trade refers to the committee, China association of enterprises of foreign trade and economic cooperation, the Chinese academy of international trade and other departments have made efforts to the skills contest and certification work. Recently, vocational qualification certification exams of cross-border electricity were held as scheduled. Skills contest and double certificate as the characteristics of vocational education, not only promote professional recognition and inspired students learning enthusiasm, and further enhance the professional quality of the students in this major. By taking part in international trade and e-commerce competition at all levels, strengthen students' vocational ability and the spirit of collaboration, communication, from passive learning into active learning and achieve "zero distance" mount guard. At the same time, the professional qualification authentication is the processes of the students consolidates what they have learned professional knowledge, to strengthen the deep understanding of professional, self supervision and improve the process. Therefore, in the whole system of international trade practice optimization reconstruction, to give full play to their skills contest and the double guide of qualification examination, combine and promote students' overall skill level.

\section{CONCLUSION}

Under the background of "Internet foreign trade", cross-border trade of electricity has become momentum of our country international trade development, the new form. It is the necessary adjustments to the timely optimization and reconstruction practice of international trade specialty course system, reshape the personnel training specification, and cope with cross-border trade trend of electricity and keep the practice of international trade specialty vitality and attraction of beneficial supplement to meet the need of employment of the enterprise.

In conclusion, under the background of the era of "Internet ", rapid development of cross-border e-commerce of higher vocational majors with the international trade practice based on cultivating of cross-border electricity traders has the characteristic construction breakthrough and opportunity. The support of National policy of the cross-border electricity suppliers, as well as cross-border electricity strong momentum of development, is the important basis for the development of cross-border e-commerce professional direction, a large number demands of talents for cross-border electricity professional direction, have good market adaptability; Favorable conditions of regional resources and related educational condition are good for the development of cross-border electricity professional providing an important safeguard.

\section{REFERENCES}

[1]. Guo Yan, "China's Booming Cross-border E-commerce", China's Foreign Trade, Feb. 2015.

[2]. Zhao Wei, "China's Cross-Border Ecommerce Embraces Golden Decades”, China's Foreign Trade, May 2014.

[3]. Zhu Zijun, "E-commerce: A Young Fast-Growing Industry in China", China's Foreign Trade, Jan. 2012.

[4]. Corrie Dosh, "Alibaba Powers Ahead". Beijing Review, 18th, 2016.

[5]. Zhou Hongmei, "China's cross-border electric business scale will exceed 4 trillion Yuan”, May 2015.

[6]. Echo Zhao, "Cross-Border Ecommerce in Bittersweet Development", China's Foreign Trade, May 2014.

[7]. Ren Chen, "Crossborder Ecommerce Value to See Heady Growth”, China's Foreign Trade, Apr. 2014. 
[8]. Echo Zhao, "Cross-Border Ecommerce in Bittersweet Development", China's Foreign Trade, May 2014.
[9]. Xu, B., "From point to point", Guangxi Normal University Press, 2012. 